The Interface between Arts Practice and Research: Attitudes and Perceptions of Australian Artist-academics.

* Dr David Wright

University of Western Sydney

School of Education

Locked Bag 1797

Penrith South DC.

NSW 1797 Australia

$\mathrm{Ph}: \quad+61-2-47360267$

Email: david.wright@uws.edu.au

Dr Dawn Bennett

Curtin University of Technology, Australia.

Dr Diana Blom University of Western Sydney, Australia. 


\section{The Interface between Arts Practice and Research: Attitudes and Perceptions of Australian Artist-academics.}

Whilst an academic working in the arts may have been appointed as a consequence of artistic accomplishment and a capacity to teach, the research that underpins such work is an intrinsic part of its production and also needs to be recognised. In Australia, the ability of the artist-academic to translate research into a form that is respected and rewarded is an issue of contention. This paper gathers responses to this issue. Perceptions of and attitudes to creative work as research are canvassed alongside life decisions arising from those perceptions and attitudes. This research occurs in the context of a new Australian framework for the evaluation of research. This framework offers some recognition of the research that supports creative practice. Thus, the long-standing experience of compromise reported by the Australian artist-academics interviewed for this study are discussed alongside new policies that seek to construct methodologies for its amelioration.

Keywords: Professional development, reflective practice, research skills.

\section{Introduction}

The creative arts have performed a variety of functions in Australian universities. Universities, like many high-profile organisations, have valued the opportunity to be identified with the arts through performances, exhibitions, residencies, events and purchases. At other times training a next generation of artists has been to the fore and this, indeed, remains a priority for a declining number of tertiary institutions. The arts have also serviced associated professions such as arts education, arts therapies and arts conservation. Beyond this, studies of artworks continue to be an important part of the liberal arts tradition. But a course on art as cultural moment is very different to a course in professional arts skills.

One reason the teaching of professional arts skills has been problematic within the Australian university system is ongoing structural change. In 1982 each state was required by the federal government to combine smaller Colleges of Advanced Education (CAEs), reducing the total from 79 to 47. Many of these Colleges ran courses in the arts and arts education. Six years later, Australian Higher Education Policy - the Dawkins Reform (Dawkins, 1998) - required institutions with less than 2,000 students to merge with a university, as a result of which CAEs and universities were combined in 1991 to create a single sector known as the unified national system (UNS). During these changes almost all of Australia's arts-schools amalgamated with universities and became departments, often devolving leadership to the non-discipline leader of a larger faculty. Further cuts to higher education in the late 1990s led to additional amalgamation and far less budgetary control at departmental level (Bennett, Blom \& Wright, 2009).

The results of the UNS have been more complex than expected and, in the context of arts education have particularly impacted funding for individual tuition and small group teaching, physical training, studios, residencies and resources. In short, "many other resource-hungry fields such as science, medicine and engineering do not see why they should be subsidizing a music school" (Hannan, 2001, p. 1).

In this regard, Newfield's critical evaluation of the period since 2000 as a time in which "the university's cultural missions have declined at the same time as leaders in politics, economics and the media have lost much of their capacity to understand the world in non-economic terms" 
(Newfield, 2008, p. 15) invites considerations upon how university attitudes to the arts currently stand.

We argue that the artist-academic, our preferred term, is a multi-faceted contributor to the contemporary university. We observe that while an artist may have gained an academic position as a consequence of artistic accomplishment and the capacity of that accomplishment to inform students, the research that stands behind that accomplishment is valued too, if only by implication. Research is an integral part of an academic's responsibility and an appointment criterion. The capacity of the artist-academic to translate the research skills that stand behind artistic accomplishment into a form valued in the university environment suggested by Newfield is central to considerations on the future of the 'artist-academic'. It also deserves to be a consideration in any imagining of the future university.

Not only is research an appointment criterion, research — especially research that generates university income - is associated with career progression. This is in part a consequence of a shift in university funding from largely government sources to a mix of government and earned income. In 1996 Australian state and federal governments provided approximately 58\% of all funds to universities with the remainder coming from fees, charges, bequests, research income and other sources. In 2005 government provided only $40 \%$ of university funds (Universities Australia, 2009).

Recognising the importance of academic publications as evidence of research accomplishment, successive governments have felt the need to make judgements about academic output. The most recent of these, Excellence for Research in Australia (ERA), was announced in February 2008 by the federal Labor government. One aspect of ERA is the ranking of research journals and the associated implication that articles published in highly ranked journals are more valuable than others. This compels academics to think about how best to systematise their knowledge: to seek acknowledgement through identified and preferred channels. It has been argued that a system of preference of this kind reflects orthodoxies within universities: "Rather than eliminating values and biases, the application of a rational framework to research activity does away only with those social values which differ from the dominant values in the academic community" (Brew, 2001, p. 86). When creative practice is insufficiently understood in the sector it is difficult for it to be accommodated in a scheme of this sort.

This is not to say that ERA has ignored creative accomplishment: the Framework acknowledges the research inherent in creative practice through four categories:

- Original (creative) works in the public domain;

- Live performance works in the public domain;

- Recorded (performance) public works; and

- Curated or produced substantial public exhibitions, events or renderings

Under the Framework, each creative work needs to be accompanied by a written narrative that articulates the research background, the contribution of new knowledge, and research significance (Gye, 2009). The written articulation of the work as research poses conceptual and philosophical challenges alongside questions around who will determine the effectiveness of each 
articulation. The Framework focus on public recognition is also at odds with the peer recognition that legitimises research in most other areas.

Despite such reservations, this recognition of creative work is welcome, as is the indication of a desire to address a previous failing. The degree to which this action ameliorates long-standing attitudes to arts practice as research and influences policies and practices in universities remains to be seen. The interviews conducted for this research suggest that a lack of recognition has been present for a considerable time and that this lack of recognition has had a considerable impact on individuals and their relationship to the institutions in which they are or have been employed.

\section{Arts practice as research}

O'Toole and Beckett (2010) describe arts practice as research as an area of "acute contemporary interests and debate" that "the university sector is quite perplexed about". They describe it as a "risky business... and the risk is in the reporting" (p. 204). Methodologically, Haseman (2006, p. 4) argues that performance-based research does "not commence with a "sense of a problem." Instead it is led by 'an enthusiasm of practice':

Practice-led researchers tend to 'dive-in', to commence practising to see what emerges. They acknowledge that what emerges is individualistic and idiosyncratic. This is not to say these researchers work without larger agendas or emancipatory aspirations, but they eschew the constraints of narrow problem solving and rigid methodological requirements at the outset of a project.

Sarah Rubidge, interviewed in 2004 for the UK-based Practice as Research in Performance (PARIP, 2004, n.p), supports this view:

I consider my research to be artistic research. I practice my research as an artist and the fact that I happen to be mediating it through an academic institution doesn't really make a great deal of difference to me. I have these artistic questions. So I just sort of go... "Thank you very much" and address them as I make work.

PARIP has been a crucible for the dissemination of practice based research (Piccini \& Kershaw, 2003). Its networks extend far and wide and its website includes interviews with practitioners and information about projects. One contributor to PARIP is Pearson $(2001,2007)$, whose performance-research is strongly grounded in place. His 2007 book In Comes I documents a personal performance project, which he describes as "scrutiny of the lived experiences of land, of interrelationship of performance and the everyday, and of the entangled nature of land, human subject and event." (2007, p. 4). Elsewhere Pearson describes his work as 'theatre/archaeology' (Pearson, 2001). This work bears discussion alongside that of Australian artist-historian Paul Carter (2004). Carter's interest in the "poetic colonisation" of Australia drove him to initiate a project with a painter, film maker, curator, dancer/choreographer and installation artist. From this, Carter reports, questions arose about:

how the process of material thinking enables us to think differently about our human situation, and, by displaying in a tangible but non-reductive form its inevitable complexity, to demonstrate 
the great role works of art can play in the ethical process of becoming (collectively and individually) oneself in a particular place." (Carter 2004, p. xii)

Writing of these collaborations, Carter constructs a work, the book Material Thinking, that is both analysis and artefact: a work from within the creative process.

The practice-research discussion ranges across the creative disciplines (see, for example Bolt, 2006; Davidson, 2004; Odam, 2001; Rubidge, 1996; Smith \& Dean, 2009). It could be argued that this work is not new and that books such as Bach's Essay on the true art of playing keyboard instruments (Part One first published 1735) and Rimsky-Korsakov's Principles of orchestration (first published 1891) are practice-led writings, drawn from the experience of the author practitioners. Accepting this, it is undeniable however that there is a more recent context within which the experience of the artist-academic, in association with the rise of research agendas in the creative industries, has given impetus to a vigorous discussion. This is at its most challenging in those forms that leave no permanent record: music, dance and other performative arts that are bound within the moment of their occurrence.

Schechner (1990) and Turner (1987) have been crucial in the attempt to systematize such experience. Turner's anthropological readings of performance - his work on 'liminality' in particular - enabled Schechner to construct models of learning that have contributed to theory and practice in contemporary performance. Work of this kind laid the foundation for Performance Studies being identified as a distinct field within the liberal-arts tradition.

There is research of equivalence across the human sciences. Richardson, for example, argues that experiments with textual voice, frame and theatre can be crucial to a researcher seeking to understand and communicate subject matter in Sociology. She believes such research has a place in overcoming troubles "with the ethical issues of doing research on others" (1997, p. 3). Denzin identifies a "performance turn in the human disciplines" (2003, p. ix), hence a need to use understanding of the performance process to develop and articulate the ethnographic imagination. Behar (1996) reports her struggles, through story telling, vulnerability and performance, to communicate an "anthropology that breaks your heart". Krieger (1991) writes of the need for a social science that is "soft, subjective, idiosyncratic, ambivalent, conflicted, about the inner life, and about experiences that cannot be measured, tested or fully shared". In effect she argues that "social science ought to be more like art" (p. 2) Springay and Freedman (2007), and O'Loughlin (2006), attempt something similar in Education within their discussions of embodiment and learning. These discussions, and others like them, are informed by feminist research and all share an interest in the form through which research is communicated.

It is the experience of 'being within' (rather than abstracted from) the arts practice and researching through that practice that forms our central subject matter here. Despite methodological shifts, a liberal arts or human sciences field of study is not the same as an artsbased or performance-based field of study. There are structural and procedural differences and, as such, there are differences required of staff who research through those fields. As Carter says: "creative knowledge cannot be abstracted from the loom that produced it" $(2004$, p. 1).

This paper is the third in a series. The first (Blom, Bennett and Wright, 2008) looked at arts practice "as a site of knowledge". The second (Bennett, Blom and Wright, 2009) looked at the 
relationship between the roles of artist, researcher and tertiary educator. This paper focuses on the attitudes of the artist-academic to the roles they are required to play in the university system. Within the second paper we investigated the concepts of 'practice-based', 'practice-led' and 'practice as' research (Rubidge, 2005) and argued that because of the embodiment of the creative process only practice-based research can be undertaken by someone other than the artist. It is in 'practice-led' and 'practice as' research that the artist-academic offers insight of a kind not available to the non-practitioner, that is, the academic theorist. This is, therefore, a reclaiming of sorts. One interviewee in this project (Ava), working in contemporary performance art, argued that many artists see academic research into their practise as 'parasitical': "Yes, it is embodied [research], but it's [research into] someone else's body". There is equivalence here with critical

responses to research into indigenous cultures. Maori academic Tuhiwai Smith (1999), argues for a reclaiming of research into indigenous cultures by indigenous peoples: those who live within the culture, its symbols, language, learning and imagination. Smith's writing resonates with both the need for agency, which in turn exposes the view of those from within the research, and with Carter's concept of abstraction.

While claiming the need for creatively informed research, there is a need for such research to be validly constructed. Rubidge argues that much of the debate about the legitimacy of creative research is driven by a perceived lack of "systematic theoretical reflection" $(2005$, p. 7$)$. The research project from which this paper stems, aims to contribute to the amelioration of this. It offers a uniquely Australian perspective, alongside much larger and more far-reaching research endeavors such as the UK-based PARIP project.

\section{The project}

This paper reports on the third question in the interview schedule: "What is your perception of, and attitude to, your roles as artist and researcher, and tertiary educator?" Research participants were identified within professional networks, and purposeful sampling was employed to locate suitable informants (Patton, 1990). Once identified, interviews were scheduled and respondents were drawn into considerations on the relationship between their practice and research.

Interviews commenced with guiding questions, shown at figure 1, then extended into more discussion of perceptions, attitudes and experiences. Despite being prompted by key questions, interviewees frequently approached significant issues indirectly. The cultivation of an interview relationship conducive to deep responsivity was central to the process. Todres (2007) describes such work as 'phenomenologically oriented' in that it values the texture of an interview as much as discrete phrases and sentences. Todres quotes Reed: "To describe the structure is to describe how the elements of a phenomenon function constitutively; how they interrelate to form the unity of the experience" (p. 8), and argues that such research "engages with accounts of experiences in a way that can articulate important understandings from those experiences ... that may be relevant to others and take inter-subjective understandings further" (p. 27). This is particularly appropriate in inquiries into creative practice, with its strong base in the relationship between embodiment and knowledge.

Figure 1: Guiding interview questions

i) How do you view your creative arts practice as a site of knowledge (that is, as research); 
ii) How do you experience the relationship and interaction between your roles as artist and researcher, and tertiary educator?

iii) What is your perception of, and attitude to, these roles?

This semi-structured interview process was used to 'draw out' the insights and experiences of the artist-academic as part of an attempt to further appreciate the research process and the means by which a range of artistic practices can be realised, notated and valued as research. These interviews have been transcribed, read and re-read by the researchers. Residual meaning has been absorbed and evaluated, and has on occasion become the stimulus to re-interview. Importantly, all interviews have been conducted by academics with a grounding in arts practices, more often than not the arts practice of the interviewee. At this stage, interviews have been recorded with eight artist-academics: two working in Theatre (Ava, Fiona), four in Music (Brian, Clare, Damon, Henry), one in Dance (Ellen) and one in Visual Arts (Gina). To preserve anonymity, all names have been fictionalised and any references to institutions have been removed.

While eight interviews were undertaken, analysis led to a decision to make four of the eight the principal focus of this article because of their relevance and focus. The four become in effect qualitative case studies (Stake, 2005) or experiential descriptions that provide learning: "How we learn from the singular case is related to how the case is like and unlike other cases we know, mostly by comparison." (p. 454) The four case study interviews were chosen for their comparative strengths. They enable boundaries to be constructed and themes to be identified. Out of themes come patterns and out of patterns the opportunity for assertions or generalisations.

The interviews, with Damon, Brian, Ellen and Ava, were perceived as representing extreme and conflicting positions on two continua. By drawing attention to the extremes of a continuum, positions within the range can be imagined. The first continuum can be described in general terms as 'attitudes towards personal arts practice as research'. The second continuum, 'specific relationships between the roles of arts practitioner and academic'. While continua are a legitimate analytical tool, our study is first and foremost a study of experienced individuals, and individuals are often multi-faceted and often conflicted within themselves. For this reason we work with individual commentaries but exert caution around overly reductive generalisations.

\section{Continuum one: attitudes towards personal arts practice as research}

Both Damon and Brian teach into the music program of a large, comprehensive university. Damon teaches composition and performance and Brian teaches electronic music. Brian is also a member of a research centre that investigates sound through an interdisciplinary perspective.

Their positions on the initial continuum of response are highlighted in the following quotes: Damon: [My practice is] not a type of research. It does contain analysis but at an intuitive or subconscious level. I almost don't want to know why the songs that I consider are successful, work.

Brian: My practice is always research for me. I'm always asking questions about the nature of what contemporary composition is. 
Damon's practice is as a songwriter and performer. As an academic he describes himself as working "in the sort of popular music studies, cultural studies area" and as "a scholar of popular music". He adds, "It's almost like at times the song writing is an aspect of that scholarship... It's an investigation into how I can make shapes that are pleasing." And it is something he incorporates into his teaching; but it is neither the subject of his research thesis nor the general orientation of his academic research. This he explains as a fear of over-analysis: "a kind of superstition":

The way that I would actually frame that is to say that I feel my song writing is an intuitive mode of research that I'm not that interested in analysing... it does contain analysis but at an intuitive or subconscious level. I almost don't want to know why the songs that I consider are successful, work. I have a kind of superstition about that almost. It's probably because of that period, where I had that group I mentioned ... I look back on that time and think that I was so self-conscious about the experiments that I was conducting ... that I think, ultimately, it made the work less successful. I think it was too selfconscious...

Damon's reluctance to make his practice the subject of his research does not extend to the practice of others. Implicit understandings gathered from personal practical experience with a variety of music almost inevitably play a role in his academic inquiries into music but his desire to separate one branch of his work-life from another deserve to be acknowledged as clear statements of choice and as a legitimate position on the continuum. As well as reflecting personal choices, Damon's preferences need to be considered in relation to the priorities of his academic employer. Questions need to be asked about pressures, subtle or otherwise, Damon may have felt in relation to his research.

In contrast, Brian, who describes his area as electro-acoustic music, composition and performance "with a particular interest in ... interactive audiovisual installations", occupies a position at the other end of the continuum. Brian insists his practice "is always research... I'm always asking questions about the nature of what contemporary composition is ... I see my work as a continuation of ... questions about composition, about musical content, about the nature of music". However, he does not view his creative output as research per se. "I'm not an advocate of the position that says that the production of the artwork is research in and of itself", he says. Instead he sees a need for artists "to expand upon the path and the discoveries that we have made and share ... because for me research is fundamentally about contributing to the discourse." And the discourse here is about the art; it may contribute to an understanding of the art and to further artistic accomplishment, but it is not the art itself.

Like Damon, Brian has a respect for the 'intuitive' within music-making. Unlike Damon he is able to position the intuitive within research: "Although there might be intuitive levels of development when we're working with sound, [this becomes] research [when] we define that for ourselves and once we've defined that ... for ourselves we talk about it ... and it contributes to the broader body of knowledge"..

Despite the overlap between functions, it is apparent that Brian draws a clear distinction between the roles of 'artist' and 'academic' and that required to work in both areas. He argues,

If you want to be an academic you need to contribute to the body of knowledge and be part of the discourse. If you don't feel the need to do that then you can just do your stuff in your studio and go 
and do your performances and so on... I don't see [that) as research... until it becomes more explicit and is shared and is open to other people.

He insists however, that his research centres on his artistic practice and his music technology needs: "I really am not interested in just doing ... research to help a company produce some interface. I want that interface to be powerful as a musical tool and I want to use that in my own practice". In this respect Brian situates his research within the academic tradition while identifying it as focussing on his own creative practice. His contribution is contained therefore within the boundaries of his personal needs.

In summary, while both musicians work with sound, and both see the compositional process as research, for the songwriter (Damon) it is an investigation that should not interfere with the compositional song-writing process. The electro-acoustic musician (Brian) views his compositional process as a continual investigation into the nature of music itself, into the nature of contemporary composition, and, specifically, into his role as composer within this lineage. Associated with this is his interest in the technology with which he makes his music.

From these musicians at two extremes of the continuum, four areas of research interest emerge: the nature of music, the nature of electro-acoustic music, one's role in the lineage of one's musical style, and the individual pleasure of shaping sounds. Whilst both musicians acknowledge the role of intuition in the creative process, analysis of the process is a topic not broached by one, and actively sought by the other. The question, therefore, is larger than whether or not the research interrogates individual artistry. Rather, it is what the researcher does and does not interrogate, and why.

\section{Continuum two: relationships between the roles of arts practitioner and academic}

The second continua of responses is illustrated in the following quotes:

Ellen: I've jumped from my life as a dancer, and now I'm an academic... I have pretty much had two lives. I gave up dance and went into academia, so (now) my dance writing is retrospective.

Ava: I am caught in the cross hairs of this debate. Half of my work is not acknowledged as having any worth in the university sector and what I have done in my university life is not necessarily valued amongst artistic decision makers... Artistic policy makers might be interested in my academic work because it comes with the imprimatur of the university... but if I were to make an artistic work... it might not be valued at all [within the university].

While no longer describing herself as a dancer, Ellen is a teacher of dance. She works in a performing arts school where the training of future artists is core business. This school has recently been attached to a university and a large part of Ellen's work involves, she says, "advocating dance as research and (looking at) ... ways in which university management can deal with this." She argues that her students need to understand that their dance feeds into research and that research skills need to be acquired and appreciated: "There's so much tacit knowledge that people don't know they have. When you (want)... to make that official, you have to justify it 
in some way." She also positions this perspective historically. In so doing she highlights the potential impact of fostering student engagement in research emanating from dance:

It's going to be easier for undergraduates now: by the time they get to postgraduate level they will have a richness of experience to draw upon. If they think that research is a normal thing to do, conceptually they'll understand. For us it was separate. We weren't encouraged to think about our dance in that way.

Emphasising the difficulties in finding time to bridge research and practice, Ellen believes that universities have become an important site for dance training. The principal cause of this is, in her mind, a perception of financial stability for dance teachers that is lacking in dance careers: "Money has driven the shift towards university life for dancers.... Outside is perceived to be tougher."

Through reference to her own practice, Ava, who at the time of interview worked in an actor training program in a comprehensive university, has a clear sense of interactions between artistic practice and academic research. "They overlap because I overlap... They overlap because of my attitude to them, because I put them into practice." From the perspective of a practitioner Ava argues that academic research has contributed to her accomplishment. "I am well read and informed and I produce work informed by critical discourse." Ava describes her arts practice as:

A place where processes... that generate knowing, understanding, ways of inquiring, speculation, hypotheses... need to be tested out... an artistic site that generates discussions, trial and error, things 'in the air', a mixture of a lot of things about how you shape bodies and sounds and words, space and time... A lot of sophisticated knowledge is drawn upon and tested... documents, academic tracts, and recordings from other mediums all these things are absorbed and critiqued.

Ava's work, which has taken the form of group rather than individual practice, is, she says, "a very social exchange of notes between groups of people with common aims". She adds:

I think Australian artists know an enormous amount about contemporary forms of academic and artistic discourse and a number of people - visitors from overseas - are astonished by the degree to which they are informed and the way they have of asking questions - a way they don't find in their home populations - it's almost a part of the identity of an Australian artist.

While suggesting the overlap of these ways of working, Ava also bears witness to the conflict. The different roles, she argues, "pull against each other and create tensions". This is primarily because of the marginalised place of arts practice. "There's not a huge body of literature that teases out knowledge and investigation in creative arts practice, it's not inside academia".

In Ava's view this conflict reaches its nadir in a perception of separation between academic and artistic work. Ava has confronted this most powerfully in her own research: "I get told my stuff doesn't rate, it doesn't count. I have been told this by senior research staff." And "I got feedback from various supervisors and readers that the kind of logic I was using in my $\mathrm{PhD}$ wasn't as linear as they were used to. ... a gentle way of saying 'it's illogical in my terms"'.

Instead of using her $\mathrm{PhD}$ to examine or comment on her own practice, Ava felt compelled to undertake a "traditionally shaped $\mathrm{PhD}$, where I was examining the thoughts and practices of other artists". This required her to be an intermediary, translating artistic expression into academic 
form: "most artists talk in a metaphoric way ... I had to interpret it ... to oscillate between interpreting' and 'holding' in order to obtain", in her words, "credibility in the academic environment... [because] this is how knowledge is produced at doctoral level." Reflecting on her decision not to undertake her doctoral research from the position of "artist-researcher", Ava said: "I didn't feel confident... because I thought my work would not be considered legitimate inside a university environment if I did." An additional consideration, one reminiscent of comments made by Ellen, was "a baseline ethical imperative that... [as] I was involved in leading the education of younger students in the university... I needed to have a clear sense of... the relationship between the knowledge that is being transmitted through the university (and) the knowledge that is arrived at through personal arts practice."

This experience of conflict is central within Ava's thoughts on contemporary university systems. Instead of imagining the future university as an environment of funded arts training, Ava imagines a less adventurous situation. One where the tertiary sector could merely provide "a sort of critical peer environment, an interested audience of [cultural] readers."

Unlike Ellen, who felt relatively comfortable situating her interest in research and practice in the tertiary sector, Ava felt sufficiently compromised that she subsequently chose to prioritise her practice and accepted a voluntary redundancy associated with the re-organisation of teaching in the performing arts at her university.

In summary, these two interviews reveal distinctly different approaches and experiences. While Ellen, the dancer, has made a deliberate choice between arts practitioner and researcher / academic, Ava, the actor has felt the need to overlap them. Her experience is frustrating, perhaps even distressing, and this becomes a major consideration in her decision to leave the sector.

Both recognise the importance of the tacit knowledge of their discipline and the need to ensure students understand that this is research. Both place value on research skills and the knowledge generated through research processes. Both see research as applicable to future arts practice for themselves and for students with whom they engage. And while both perceive research in this way both have felt the need to make very significant choices that compromise the learning that has formed them as people within a community of practice that they value. Crucially, this is a community of practice they teach students to value and make their way in as well. From one perspective, this could be seen as ironic, perhaps even tragic. From another perspective it can be seen as that which is required to be accommodated within the utilitarian functioning of a corporate structure driven by a need to survive in pressured financial circumstances.

\section{Concluding comments}

Playwright Brian Friels (in Gallagher, 2008) views the arts as an elusive study:

The arts grow and wither and expand and contract erratically and sporadically. Like beachcombers or Irish tinkers they live precariously, existing from idea to idea, from theory to theory, from experiment to experiment. They do owe something to the tradition in which they grow; and they bear some relationship to current economic and political trends. But they are what they are at any given time and in any given place because of the condition and climate of thought that prevail at that time and in that place... Impermanence is the only constant. 
There are difficulties in accommodating erratic and sporadic beachcombers and tinkers, Irish or otherwise, and their artistic activities, in formally structured educational settings. These four case studies offer insight into the challenges encountered by artists employed in the tertiary sector in Australia. Each suggests that artists are not easily accommodated because governing systems are insufficiently able to appreciate the research that supports an arts practice. While recognising the priorities given to the conventional notation of research through written publications, each of the artists understands the research that supports creative practice cannot be fully contained within this form. In addition, each, to varying degrees, recognises the power of the institution to shape the ways in which employees communicate their understanding over time. Subtle forms of colonisation contribute to patterns of communication. This can be resisted, or it can be worked with. In this respect, individuals do make personal choices. Nothing, except their commitment to their art, precludes them from developing the skills to work in relatively traditional academic ways. These ways of working are not, of necessity, antithetical to artistic accomplishment; but they do require re-orientation, re-learning, re-assessment of assumptions and a considerable commitment of time.

We argue that artist-academics should be encouraged to engage in the many available forms of creative approaches to research. Within this work lie benefits for students and research cultureboth traditional and creative - within universities, and within society. These approaches are particularly beneficial to methodological developments in qualitative inquiry. Gallagher (2008) writes of the 'art of methodology', which is increasingly seen as an interpretive form with relevance within and beyond the arts. Despite difficulties such as those encountered by artistacademics whose arts practice is not primarily in the written word or artists whose arts practice is 'real-time' or performative, we argue that it is in the best interests of the institution to create an environment within which this sort of work can be valued.

The introduction of the ERA marks this as a logical time for such an environment to be developed, coming as it does as after a decade in which only four categories of research output were recognized for funding: peer reviewed journal articles, fully refereed conference papers, books, and book chapters. However, the powerful medico-scientific focus remains and expectations of ERA are mixed. Damon, the songwriter, while considering himself not well informed about ERA says: "what I have gathered has encouraged me to consider some of my performance and composition work as research". He welcomes acknowledgement, "so long as that doesn't necessitate writing about that work". Ellen also regards it as a positive move, complicated by the need to develop appropriate methods for the valuing and assessment of research. Brian, however, describes himself as sceptical:

The current journal rankings devalue journals in my area and practice-driven discussions, heavily weighting journals focused on traditional musicology. I think this is an indication of what is to come, which is a lot of hot air about practice being acknowledged... but very little actually changing on the ground.

Recent publications that document responses to the ERA concur with our findings and suggest a climate of tempered enthusiasm. Gye (2009, n. p), for example, cites Ross Gibson, Professor of Contemporary Arts at Sydney University: 
It [ERA] will benefit artists who are able to engage in some extra, fairly traditional routines of academic scholarship, adding some linguistic discourse onto their productions. The ERA probably won't benefit artists who happen to teach in academies but who are not that interested in being the new-style creative arts academic. The rules are pretty clear - knowledge has to be made explicit and communicated. The arguments will occur over whether the creative artwork, standing alone, is explicitly communicated knowledge. My reading of the national intellectual scene is that we're nowhere near persuading enough people that this is true.

On an institutional level, Bennett (2009, n. p) argues that the inclusion of creative research within the ERA will have limited impact in universities that have not previously valued and, therefore collected data on, creative research undertaken by faculty. Universities that have collected this data, despite it not being measured nationally will be, she argues, "ideally positioned to engage with ERA".

Ultimately, university response to the ERA will play a major role in determining perceptions of, and attitudes towards, the roles of artist, pedagogue and academic in Australian universities into the future. Our interviews confirm that artist-academics have felt compromised and marginalised. This has affected how they have valued their contributions to society and their workplace, and the decisions they have made about the forms of work they have undertaken. ERA is not in itself the solution, but it does suggest broader recognition of a concern shared by many artist-academics.

\section{References}

Behar, R. (1996). The vulnerable observer. Boston: Beacon Press.

Bennett, D. (2009). Education and the arts: music. New rules: the research game. RealTime (92). Retrieved August 12th, 2009, from http://www.realtimearts.net/article/92/9507

Bennett, D., Blom, D., \& Wright, D. (2009). Artist academics: Performing the Australian research agenda. International Journal of Education and the Arts, 10(17). Retrieved May 22nd, 2009, from http://www.ijea.org/v10n17/index.html

Blom, D., Bennett, D., \& Wright, D. (2008). The artist as academic: Arts practice as research. In J. Southcott (Ed.), 30 ${ }^{\text {th }}$ Annual Conference of the Australian and New Zealand Association for Research in Music Education. Melbourne: Monash University, 15-25.

Bolt. B. (2006). A non standard deviation: Handlability, praxical knowledge and practice-led research. In 'Speculation and Innovation', Special issue Real Retrieved May $22^{\text {nd }}, 2009$, from http://www.speculation2005.qut.edu.au/

Time Arts .

Brew, A. (2001). The Nature of Research. London: Routledge/Falmer.

Carter, P. (2004). Material thinking - The theory and practice of creative research. Melbourne: Melbourne University Press.

Davidson, J. (2004). Making a reflexive turn: Practical music-making becomes conventional research. In J. Davidson (Ed.) The music practitioner - Research for the music performer, teacher and listener (pp. 133-149). England: Ashgate.

Dawkins, J. (1998). Higher education policy. A policy statement. Canberra, ACT: Australian Government Publishing Service.

Denzin, N. (2003). Performance ethnography: Critical pedagogy and the politics of culture. Thousand Oaks, CA: Sage Publishing, Inc. Gallagher, K. (ed). (2008). The methodological dilemma. London: Routledge. Gye, L. (2009). Education and the media arts: Positive initiatives, problematic implications. RealTime (92). Retrieved August 12th, 2009, from http://www.realtimearts.net/article/92/9523 
Hannan, M. (2001). The future of tertiary music training in Australia. Australian Music Forum, 7(3).

Krieger, S. (1991). Social science and the self. New Brunswick, NJ: Rutgers University Press. Newfield, C. (2008). Unmaking the public university. Cambridge, Mass.: Harvard University Press.

Odam, G. (2001). Research in the arts: Issues in the development of new and relevant techniques of arts research in music, the arts and arts education. Music Education Research, 3(1), 77-86. O'Loughlin, M. (2005). Embodiment and education: Exploring creatural existence. Dordrecht, Netherlands: Springer.

O’Toole, J. \& Beckett, D. (2010) Educational research: Creative thinking and doing. South Melbourne, Victoria: Oxford University Press.

PARIP (Practice as Research in Performance). Art texts. Retrieved August 15th, 2006, from http://www.bris.ac.uk/parip/artexts.htm

Patton, M. (1990). Qualitative evaluation and research methods (2nd ed.). Thousand Oaks, CA:

Sage Publishing, Inc.

Pearson, M. (2006) In comes I. Exeter: University of Exeter Press.

Pearson, M. (2001). Theatre/archaeology. London: Routledge

Piccini, A., \& Kershaw, B. (2003). Practice as research in performance: From epistemology to evaluation. In Journal of Media Practice 4(2), 113-123

Richardson, L. (1997). Fields of play. New Brunswick, NJ: Rutgers University Press.

Rubidge, S. (1996). Does authenticity matter? The case for and against authenticity in the performing arts. In P. Campbell (Ed.), Analysing performance - A critical reader, Manchester: Manchester University Press.

Rubidge, S. (2005). Artists in the academy: Reflections on artistic practice as research. Paper presented at Dance Rebooted: Initialising the Grid, Deakin University, December. Retrieved October 17th, 2007, from

http://www.ausdance.org.au/resources/publications/rebooted/rebootedpdfs/Rubidge.pdf

Springay, S., \& Freedman, D. (Eds.). (2007). Curriculum and the cultural body. New York: Peter Lang Publishing.

Smith, H. \& Dean, R. (2009) Practice-led research, research-led practice: Towards the iterative cycle web. In Smith, H. \& Dean, R. T. (Eds.) (2009) Practice-led research, research-led practice in the creative arts Sydney, NSW: UNSW Press.

Smith, L. (1999). Decolonising methodologies, London: Zed Books.

Stake, R. E. (2005). Qualitative case studies, In N. Denzin \& Y. Lincoln (Eds.), The SAGE handbook of qualitative research, $3^{\text {rd }}$ edn. Thousand Oaks: Sage publications.

Todres, L. (2007). Embodied enquiry. London: Palgrave Macmillan.

Universities Australia. (2009). Retrieved August 11th, 2009, from

http://www.universitiesaustralia.edu.au/content.asp?page=/universities/overview.htm

Word count: 6697

Word count (plus abstract): 6845 